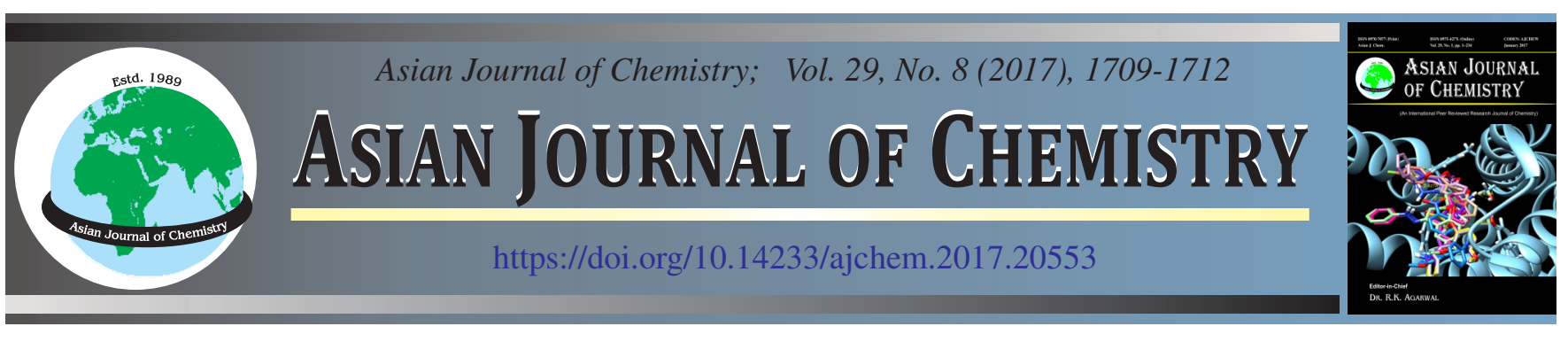

\title{
An Efficient and Green Synthesis of Imidazoles Using Natural Organic Acids as Promoter under Solvent-Free Condition
}

Kiran D. Dhawale, Nitin M. Thorat and Limbraj R. Patil ${ }^{*}$

Department of Chemistry, Maharaja Jivajirao Shinde Arts, Science, Commerce College, Shrigonda-413 701, India

*Corresponding author: E-mail: limbrajp@gmail.com

Received: 30 January 2017;

Accepted: 12 April 2017;

Published online: 12 June 2017;

AJC-18427

An efficient and eco-friendly synthesis of imidazoles, promoted by naturally occurring acids, via condensation of benzil, aldehyde and ammonium acetate using conventional and microwave heating under solvent-free condition is described. Reactions under microwave irradiation are faster and gave slightly higher yields against conventional heating.

Keywords: Imidazoles, Green synthesis.

$$
\text { L }
$$

L -

\section{INTRODUCTION}

Due to the growing concern over environmental pollution, green chemistry has attracted an increasing interest in recent years [1-4]. Intensive efforts have been focused on designing and developing economical and environmentally benign syntheses. Major environmental pollution is arising from the use of solvents since the amounts of solvents used are usually much larger than the amounts of reagents and products. The problem may be addressed by recycling the solvents which is economically as well as practically difficult. Much of the research is being pursued vigorously for the replacement of conventional organic solvents which are highly volatile, environmentally harmful and/or biologically incompatible by environmentally benign solvents. Ionic liquids and fluorous solvents have been used with their limitations in organic syntheses. The poor solubility of organic molecules in water has restricted its use as benign solvent in organic synthesis. Due to the toxicity of organic solvents and limitations of environmentally benign solvents, the most promising approach is to perform organic reactions under solvent-free conditions. Solvent-free reactions have received considerable attention in recent years, not only for ecological and economical reasons, but also for simplicity of reaction conditions, high yields and short reaction times. Another source of environmental pollution is use of large amount of acid catalysts in organic reactions which generates toxic waste that is harmful to the environment. The development of low-cost, naturally occurring, green acid catalyst could change the traditional procedures into green ones, thus minimizing chemical waste further. Therefore the use of naturally occurring, green acid catalyst under solvent free condition would be better solution to the environmental pollution.

Large number of organic acids exists in nature which possesses immense potential as green catalyst in synthetic organic transformations. These acids are nontoxic, readily and easily available from nature. The biological and pharmacological activity as well as the therapeutic, cosmetic and nutritional potential of these acids and their derivatives is wellknown. However, despite the fact that these acids are biodegradable and renewable from nature, their synthetic potential as green catalysts in organic reactions has been ignored to a large extent except for a few scattered reports in the literature [5]. The growing demand for clean and efficient chemical synthesis under solvent-free conditions, which when coupled with naturally occurring acids as green catalyst and microwave irradiation, provides a green approach required for both economical and environmental perspectives. Naturally occurring organic acids can be used as green catalyst in organic reactions as they are nontoxic, readily and easily available in nature. There are few reports on the application of natural organic acids in the organic synthesis [6,7].

Naturally occurring substituted imidazoles, as well as synthetic derivatives thereof, exhibit wide ranges of biological activities as well as the synthesis of them attractive compounds for organic chemists. They act as inhibitors of p38 MAP kinase [8], transforming growth factor b1 (TGF-b1) type 1 active in receptor-like kinase (ALK5) [9], B-Raf kinase [10], biosynthesis of interleukin-1 (IL-1) [11] and cyclooxygenase-2 (COX2) [12]. Appropriately substituted imidazoles are extensively 
used as CB1 cannabinoid receptor antagonists [13] and glucagon receptors [14], antibacterial and antitumor agents [15] and modulators of P-glycoprotein (P-gp)-mediated multidrug resistance (MDR) [16] and also as pesticides [17]. Recent advances in green chemistry and organometallic catalysis has extended the application of imidazoles as ionic liquids [18] and N-heterocyclic carbenes [19]. Due to their wide range of pharmacological activity, industrial and synthetic applications, a number of methods [20-22] have been reported for the synthesis of imidazoles and its derivatives. These methods include the coupling of benzil and aromatic aldehydes. We report here a simple, mild, green and efficient method for synthesis of imidazoles in presence of natural organic acids under solvent free condition by using microwave heating.

\section{EXPERIMENTAL}

Reactions were performed in oven-dried glassware and monitored by TLC silica gel plates (60 F254) which were visualized by $\mathrm{UV}$ and $\mathrm{KMnO}_{4}$ solution. All the solvents and reagents were used as obtained from commercial source. Melting points (uncorrected) were determined in open capillary tubes using paraffin oil bath. All the microwave-assisted reactions were performed in Discover Lab Met microwave system (CEM Corporation, USA) at the specified temperature using the standard mode of operation. Standard ${ }^{1} \mathrm{H}$ NMR and ${ }^{13} \mathrm{C}$ NMR were recorded on a Varian mercury spectrometer at 300 and $75 \mathrm{MHz}$ respectively in $\mathrm{CDCl}_{3}$ solution and with TMS as an internal standard. Infrared spectra were recorded on Perkin Elmer Model 1600 series FTIR instrument.

General procedure for synthesis of imidazoles: The mixture of aromatic aldehyde $\mathbf{1 a}(0.5 \mathrm{~mL}, 4.904 \mathrm{mmol})$, urea 2 (0.30 g, $4.904 \mathrm{mmol})$, ethyl acetoacetate 3 (0.62 mL, 4.904 $\mathrm{mmol})$ and malic acid $(0.657 \mathrm{~g}, 4.904 \mathrm{mmol})$ was heated either in an oil bath, preheated at $140{ }^{\circ} \mathrm{C}$ for $10 \mathrm{~min}$ or in microwave reactor for $5 \mathrm{~min}$ After completion of reaction (TLC check), the reaction mixture was allowed to cool at room temperature and water $(10 \mathrm{~mL})$ was added. The solid obtained on stirring was filtered and washed with water. Crude product was purified by recrystallization using aqueous ethanol.

\section{RESULTS AND DISCUSSION}

Screening of naturally occurring organic acid promoters: The screening of the catalysts, for synthesis of imidazoles derivatives 1a, 2a and $\mathbf{3 a}$ was selected as a model reaction. Initially, 1a (0.5 g, $2.378 \mathrm{mmol}), \mathbf{2 a}(0.25 \mathrm{~g}, 2.378 \mathrm{mmol}), \mathbf{3 a}$ $(0.22 \mathrm{~g}, 2.85 \mathrm{mmol})$ and citric acid $(0.45 \mathrm{~g}, 2.378 \mathrm{mmol})$ (Table-1, entry 1), were heated either in an oil bath, preheated at $160{ }^{\circ} \mathrm{C}$ for $20 \mathrm{~min}$ or in microwave reactor for $10 \mathrm{~min}$ to yield imidazoles $4 \mathbf{a}$ (76\% and $85 \%$ respectively) (Table-1, entry 1). The results with other organic acids indicate that all the acids act as effective promoters to give imidazoles $\mathbf{4 a}$ in good to excellent yields (Table-1, entry 2-7). Microwave irradiation reduces time (10 $\mathrm{min}$ ) and improves the yields as compared to conventional heating. In this screening study citric acid (Table-1, entry 1), malonic acid (Table-1, entry 4) and oxalic acid (Table-1, entry 5) turned out to be better catalysts than fumaric acid (Table-1, entry 2), succinic acid (Table-1, entry 7) and tartaric acid (Table-1, entry 6), whereas best results were obtained by using malic acid (Table-1, entry 3 ).

Standardization of reaction condition and preparation of compounds: For standardization of imidazoles derivatives, initially $\mathbf{1 a}(0.5 \mathrm{~g}, 2.378 \mathrm{mmol}), \mathbf{2 a}(0.25 \mathrm{~g}, 2.378 \mathrm{mmol}), \mathbf{3 a}$ $(0.22 \mathrm{~g}, 2.85 \mathrm{mmol})$ were heated either in an oil bath, preheated at $140{ }^{\circ} \mathrm{C}$ for $20 \mathrm{~min}$ or in microwave reactor for $10 \mathrm{~min}$ For this, we first examined the synthesis of 2,4,5-triphenyl- $1 \mathrm{H}$ imidazole $4 \mathbf{a}$ in the presence of $0.1(0.03 \mathrm{~g}, 0.238 \mathrm{mmol})$ equivalent of malic acid. While performing conventional heating, after $60 \mathrm{~min}$ of reaction time, the desired product $4 \mathbf{a}$ was formed in a low amount (Table-2, entry 1). Using 0.2 $(0.06 \mathrm{~g}, 0.47 \mathrm{mmol})$ and $0.4(0.13 \mathrm{~g}, 0.95 \mathrm{mmol})$ equivalent of malic acid afforded the preferred product with moderate yields (Table-2, entries 2 and 3), while using 0.6 (0.19 g, 1.42 mmol) and $0.8(0.25 \mathrm{~g}, 1.90 \mathrm{mmol})$ equivalent of malic acid there was slight but not considerable increase in the yield of the product (Table-3, entry 4 and 5). To see the effect of amount of catalyst on reaction yield, we used $1.2(0.38 \mathrm{~g}, 2.85 \mathrm{mmol})$ equivalents of malic acid under same reaction condition. But we were surprise to found that there was no further improvement in the reaction.

\begin{tabular}{|c|c|c|c|c|c|c|}
\hline \multirow{3}{*}{ Entry } & CREENING & YSTS FOR IMI & $\begin{array}{l}\text { TABLE-1 } \\
\text { LES SYNTH } \\
\underset{\text { rganic acid }}{\stackrel{\mathrm{NH}_{4} \mathrm{OAC}}{ }} \\
\text { 3a }\end{array}$ & NDER SOL & REE CONDI & \\
\hline & \multirow{2}{*}{ Acid } & \multirow{2}{*}{$\begin{array}{c}\text { Temperature } \\
\left({ }^{\circ} \mathrm{C}\right)\end{array}$} & \multicolumn{2}{|c|}{ Conventional heating } & \multicolumn{2}{|c|}{ Microwave heating } \\
\hline & & & Time (min) & Yield $^{\mathrm{c}}(\%)$ & Time (min) & Yield $^{\mathrm{c}}(\%)$ \\
\hline 1 & Citric & 160 & 20 & 76 & 10 & 85 \\
\hline 2 & Fumaric & 290 & 20 & 65 & 10 & 75 \\
\hline 3 & Malic & 140 & 20 & 78 & 10 & 89 \\
\hline 4 & Malonic & 140 & 20 & 80 & 10 & 83 \\
\hline 5 & Oxalic & 110 & 20 & 77 & 10 & 86 \\
\hline 6 & Succinic & 190 & 20 & 68 & 10 & 74 \\
\hline 7 & Tartaric & 180 & 20 & 75 & 10 & 79 \\
\hline
\end{tabular}

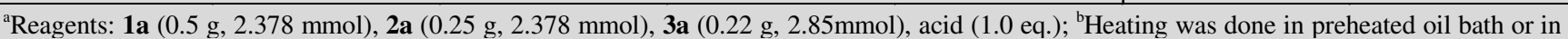
microwave reactor; ${ }^{\mathrm{c}}$ Isolated yields. 


\begin{tabular}{|c|c|c|c|c|c|}
\hline \multirow[b]{3}{*}{ Entry } & \multicolumn{5}{|c|}{$\begin{array}{l}\text { TABLE-2 } \\
\text { SFFECT OF AMOUNT OF CATALYST ON THE } \\
\text { 2,4,5-TRIPHENYL- } 1 H \text {-IMIDAZOLE }\end{array}$} \\
\hline & \multirow{2}{*}{$\begin{array}{l}\text { Catalyst } \\
\text { (equiv) }\end{array}$} & \multicolumn{2}{|c|}{ Conventional heating } & \multicolumn{2}{|c|}{ Microwave heating } \\
\hline & & $\begin{array}{l}\text { Time } \\
(\mathrm{min})\end{array}$ & $\begin{array}{c}\text { Yield } \\
(\%)\end{array}$ & $\begin{array}{l}\text { Time } \\
\text { (min) }\end{array}$ & $\begin{array}{c}\text { Yield } \\
(\%)\end{array}$ \\
\hline 1 & 0.1 & 60 & 17 & 60 & 20 \\
\hline 2 & 0.2 & 20 & 35 & 20 & 36 \\
\hline 3 & 0.4 & 20 & 42 & 20 & 48 \\
\hline 4 & 0.6 & 20 & 56 & 20 & 60 \\
\hline 5 & 0.8 & 20 & 64 & 20 & 72 \\
\hline 6 & 1.0 & 20 & 78 & 20 & 89 \\
\hline 7 & 1.2 & 20 & 78 & 20 & 89 \\
\hline
\end{tabular}

\begin{tabular}{|c|c|c|c|c|}
\hline \multicolumn{5}{|c|}{$\begin{array}{c}\text { TABLE-3 } \\
\text { MALIC ACID CATALYZED SYNTHESIS OF IMIDAZOLES } \\
\text { VIA THE CONDENSATION OF BENZIL, ALDEHYDE AND } \\
\text { AMMONIUM ACETATE UNDER SOLVENT FREE CONDITION }\end{array}$} \\
\hline & 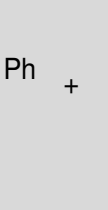 & $2 a$ & Malic Acid & $\underset{4 a-m}{H}$ \\
\hline \multirow[b]{2}{*}{ Entry } & \multirow[b]{2}{*}{ Compd. } & \multirow[b]{2}{*}{$\mathrm{Ar}$} & \multicolumn{2}{|c|}{ Isolated yields (\%) } \\
\hline & & & $\begin{array}{c}\text { Conventional } \\
\text { heating }^{\mathrm{b}}\end{array}$ & $\begin{array}{c}\text { Microwave } \\
\text { heating }^{\mathrm{b}}\end{array}$ \\
\hline 1 & $4 a$ & $\mathrm{Ph}$ & 76 & 85 \\
\hline 2 & $4 b$ & $p-\mathrm{MeC}_{6} \mathrm{H}_{4}$ & 73 & 81 \\
\hline 3 & $4 c$ & $p-\mathrm{MeOC}_{6} \mathrm{H}_{4}$ & 74 & 82 \\
\hline 4 & 4d & $p-\mathrm{FC}_{6} \mathrm{H}_{4}$ & 75 & 80 \\
\hline 5 & $4 e$ & $p-\mathrm{ClC}_{6} \mathrm{H}_{4}$ & 72 & 82 \\
\hline 6 & $4 f$ & $p-\mathrm{BrC}_{6} \mathrm{H}_{4}$ & 76 & 83 \\
\hline 7 & $4 g$ & $p-\mathrm{NO}_{2} \mathrm{C}_{6} \mathrm{H}_{4}$ & 77 & 84 \\
\hline 8 & $4 h$ & $p-\mathrm{CNC}_{6} \mathrm{H}_{4}$ & 71 & 82 \\
\hline 9 & $4 i$ & $\begin{array}{l}m-\mathrm{MeO} p- \\
\mathrm{MeOC}_{6} \mathrm{H}_{4}\end{array}$ & 72 & 80 \\
\hline 10 & $4 j$ & $\mathrm{Ph}$ & 70 & 81 \\
\hline 11 & $4 k$ & $p-\mathrm{MeC}_{6} \mathrm{H}_{4}$ & 72 & 79 \\
\hline 12 & 41 & $p-\mathrm{FC}_{6} \mathrm{H}_{4}$ & 74 & 78 \\
\hline 13 & $4 m$ & $p-\mathrm{ClC}_{6} \mathrm{H}_{4}$ & 74 & 80 \\
\hline
\end{tabular}

${ }^{a}$ Reagents: 1a $(0.5 \mathrm{~g}, 2.378 \mathrm{mmol})$, 2a Various aldehyde $(0.25 \mathrm{~g}, 2.378$ $\mathrm{mmol}$ ), malic acid (0.318 g, $2.378 \mathrm{mmol})$;

${ }^{b}$ Heating was done in preheated oil bath or in microwave reactor.

Finally it is noticed that $1.0(0.31 \mathrm{~g}, 2.37 \mathrm{mmol})$ equivalent of malic acid was the most appropriate amount of catalyst for achieving the desired conversion (Table-2, entry 6). Similarly, by applying the same strategy under microwave irradiation, we observed that the time taken for completion of reaction have now decreased to half of the time taken by convention heating (Table-2). It clearly shows that as the amount of malic acid increases there is a gradual increase in the reaction yield. However, after using excess of malic acid there is not much improvement in the reaction yield.

Next, to explore the diversity of this methodology, various substituted benzaldehyde were tested under the above reaction condition. Results showed that the formation of imidazole took place smoothly to completion within a short reaction time in good to excellent yields under both heating conditions (Table-3, entry 1-13).

\section{Conclusion}

In conclusion, we found that the naturally occurring acids like citric acid, oxalic acid, tartaric acid, malic acid, succinic acid, malonic acid and fumaric acid can be used as an environment-friendly acid catalyst for synthesis of imidazoles under solvent free condition in short time. Malic acid showed superior reactivity under conventional as well as microwave irradiation conditions. Further, results indicated that microwave irradiation reduced reaction time and gave slightly higher yields against conventional heating. The operational simplicity, use of commercially available, biodegradable and renewable natural catalysts, solvent free reaction condition, short reaction time, easy work up and high yields makes these catalysts a more convenient alternative to the reported catalysts. The application of this protocol to other synthetic reactions is under investigation.

\section{ACKNOWLEDGEMENTS}

The authors thank Principal Dr. D.K. Mhaske, M.J.S. College, Shrigonda, India for helpful discussion and suggestions.

\section{REFERENCES}

1. P.T. Anastas and T.C. Williamson, Green Chemistry: Frontiers in Benign Chemical Syntheses and Processes, Oxford Science Publications, New York (1998).

2. A.S. Matlack, Introduction to Green Chemistry, Marcel Dekker, Inc., New York (2001).

3. M. Poliakoff and P.T. Anastas, Nature, 413, 257 (2001); https://doi.org/10.1038/35095133.

4. J.M. DeSimone, Science, 297, 799 (2002); https://doi.org/10.1126/science.1069622.

5. (a) S. Chandrasekhar and K. Gopalaiah, Tetrahedron Lett., 44, 7437 (2003); https://doi.org/10.1016/i.tetlet.2003.08.038.

6. Suresh, A. Saini, D. Kumar and J.S. Sandhu, Green Chem. Lett. Rev., 2, 29 (2009); https://doi.org/10.1080/17518250902973833.

7. A. de Vasconcelos, P.S. Oliveira, M. Ritter, R.A. Freitag, R.L. Romano, F.H. Quina, L. Pizzuti, C.M.P. Pereira, F.M. Stefanello and A.G. Barschak, J. Biochem. Mol. Toxicol., 26, 155 (2012); https://doi.org/10.1002/jbt.20424.

8. (a) G.L. Gravatt, B.C. Baguley, W.R. Wilson and W.A. Denny, J. Med. Chem., 37, 4338 (1994);

https://doi.org/10.1021/jm00051a010.

(b) J.S. Kim, B. Gatto, C. Yu, A. Liu, L.F. Liu and E.J. La Voie, J. Med. Chem., 39, 992 (1996);

https://doi.org/10.1021/jm950412w.

(c) T. Roth, M.L. Morningstar, P.L. Boyer, S.H. Hughes, R.W. Buckheit and C.J. Michejda, J. Med. Chem., 40, 4199 (1997); https://doi.org/10.1021/jm970096g.

(d) D.A. Horton, G.T. Bourne and M.L. Smythe, Chem. Rev., 103, 893 (2003);

https://doi.org/10.1021/cr020033s.

9. (b) B. Jayashankara and K.M. Lokanatha Rai, ARKIVOC, 75 (2008); https://doi.org/10.3998/ark.5550190.0009.b07.

(c) T. Roth, M.L. Morningstar, P.L. Boyer, S.H. Hughes, R.W. Buckheit Jr. and C.J. Michejda, J. Med. Chem., 40, 4199 (1997); https://doi.org/10.1021/jm970096g.

(d) S.N. Lin and L.H. Yang, Tetrahedron Lett., 46, 4315 (2005); https://doi.org/10.1016/j.tetlet.2005.04.101.

(e) J. Valdez, R. Cedillo, A. Hernandez-Campos, L. Yepez, F. HernandezLuis, G. Navarrete-Vazquez, A. Tapia, R. Cortes, M. Hernández and R. Castillo, Bioorg. Med. Chem. Lett., 12, 2221 (2002); https://doi.org/10.1016/S0960-894X(02)00346-3.

(f) A.R. Porcari, R.V. Devivar, L.S. Kucera, J.C. Drach and L.B. Townsend, J. Med. Chem., 41, 1252 (1998); https://doi.org/10.1021/jm970559i. 
(g) K.C. Ravindra, H.M. Vagdevi and V.P. Vaidya, ARKIVOC, 1 (2008); https://doi.org/10.3998/ark.5550190.0009.b01.

10. (a) C. Hubschwerlen, P. Pflieger, J.L. Specklin, K. Gubernator, H. Gmuender, P. Angehrn and I. Kompis, J. Med. Chem., 35, 1385 (1992); https://doi.org/10.1021/jm00086a006.

(b) J.S. Kim, Q. Sun, B. Gatto, C. Yu, A. Liu, L.F. Liu and E.J. LaVoie, Bioorg. Med. Chem., 4, 621 (1996); https://doi.org/10.1016/0968-0896(96)00047-8.

(c) D.F. Shi, T.D. Bradshaw, S. Wrigley, C.J. McCall, P. Lelieveld, I. Fichtner and M.F.G. Stevens, J. Med. Chem., 39, 3375 (1996); https://doi.org/10.1021/jm9600959.

11. (a) Y. He, J. Yang, B. Wu, L. Risen and E.E. Swayze, Bioorg. Med. Chem. Lett., 14, 1217 (2004); https://doi.org/10.1016/j.bmcl.2003.12.051.

(b) I I. Yildiz-Oren, I. Yalcin, E. Aki-Sener and N. Ucarturk, Eur. J. Med. Chem., 39, 291 (2004); https://doi.org/10.1016/j.ejmech.2003.11.014.

(c) J.M. Gardiner, C.R. Loyns, A. Burke, A. Khan and N. Mahmood, Bioorg. Med. Chem. Lett., 5, 1251 (1995); https://doi.org/10.1016/0960-894X(95)00203-6.

12. (a) Y. Bai, J. Lu, Z. Shi and B. Yang, Synlett, 544 (2001); https://doi.org/10.1055/s-2001-12339.

(b) E. Hasegawa, A. Yoneoka, K. Suzuki, T. Kato, T. Kitazume and K. Yanagi, Tetrahedron, 55, 12957 (1999); https://doi.org/10.1016/S0040-4020(99)00804-2.

13. (a) R.W.Middleton and D.G. Wibberley, J. Heterocycl. Chem., 17, 1757 (1980); https://doi.org/10.1002/jhet.5570170824.

(b) T. Hisano, M. Ichikawa, K. Tsumoto and M. Tasaki, Chem. Pharm. Bull. (Tokyo), 30, 2996 (1982); https://doi.org/10.1248/cpb.30.2996.

(c) T.A. Fairley, R.R. Tidwell, I. Donkor, N.A. Naiman, K.A. Ohemeng, R.J. Lombardy, J.A. Bentley and M. Cory, J. Med. Chem., 36, 1746 (1993); https://doi.org/10.1021/jm00064a008.

(d) A. Czarny, W.D. Wilson and D.W. Boykin, J. Heterocycl. Chem., 33, 1393 (1996): https://doi.org/10.1002/ihet.5570330463.

14. (a) F.F. Stephens and J.D. Bower, J. Chem. Soc., 2971 (1949); https://doi.org/10.1039/jr9490002971. (b) H. Chikashita, S. Nishida, M. Miyazaki, Y. Morita and K. Itoh, Bull. Chem. Soc. (Japan), 60, 737 (1987);

https://doi.org/10.1246/bcsj.60.737.

(c) S. Kumar, V. Kansal and A. Bhaduri, Indian J. Chem., 20B, 254 (1991); (d) F. Pätzold, F. Zeuner, T. Heyer and H.-J. Nielas, Synth. Commun., 22, 281 (1992);

https://doi.org/10.1080/00397919208021304.

(e) R.L. Lombardy, F.A. Tanious, K. Ramachandran, R.R. Tidwell and W.D. Wilson, J. Med. Chem., 39, 1452 (1996); https://doi.org/10.1021/jm9507946.

(f) P.L. Beaulieu, B. Hache and E. von Moos, Synthesis, 1683 (2003); https://doi.org/10.1055/s-2003-40888.

15. (a) Z.-H. Zhang, L. Yin and Y.-M. Wang, Catal. Commun., 8, 1126 (2007); https://doi.org/10.1016/j.catcom.2006.10.022.

(b) Z.H. Zhang, L. Yin, Y. Li and Y.M. Wang, Tetrahedron Lett., 46, 889 (2005); https://doi.org/10.1016/j.tetlet.2004.11.161.

16. (a) C. Chen and Y.J. Chen, Tetrahedron Lett., 45, 113 (2004); https://doi.org/10.1016/j.tetlet.2003.10.095.

(b) J.P. Mayer, G.S. Lewis, C. McGee and D. Bankaitis-Davis, Tetrahedron Lett., 39, 6655 (1998); https://doi.org/10.1016/S0040-4039(98)01427-0.

17. V. Sareen, U. Gupta, V. Khatri and S. Chug, Indian J. Heterocycl. Chem., 17, 355 (2008)

18. S.A. Siddiqui, U.C. Narkhede, S.S. Palimbar, T. Danial, R.J. Lahoti and K.V. Srinivasan, Tetrahedron, 61, 3539 (2005); https://doi.org/10.1016/j.tet.2005.01.116.

19. F.E. Hahn and M.C. Jahnke, Angew. Chem., 120, 3166 (2008); https://doi.org/10.1002/ange.200703883.

20. M. Suzuki, S. Maeda and K. Matsumoto, Boll. Chim. Farm., 34, 3111 (1986).

21. L. Almirante, A. Mugnaini, P. Rugarli, A. Gamba, E. Zefelippo, N.D. Toma and W. Murmann, J. Med. Chem., 12, 122 (1969); https://doi.org/10.1021/jm00301a031.

22. F. Suzuki, T. Kuroda, T. Tamura, S. Sato, K. Ohmori and S. Ichikawa, J. Med. Chem., 35, 2863 (1992);

https://doi.org/10.1021/jm00093a020. 